\title{
INFLASI DI INDONESIA PADA PERIODE 2011-2015: ANALISIS SERTIFIKAT BANK INDONESIA, SERTIFIKAT BANK INDONESIA SYARIAH, PASAR UANG ANTAR BANK, PASAR UANG ANTAR BANK SYARIAH, FINANCE TO DEPOSIT RATIO DAN LOAN TO DEPOSIT RATIO
}

\author{
Achmad Adnan Fauzi Wicaksana \\ Mahasiswa Program Studi S1 Ekonomi Islam-Fakultas Ekonomi dan Bisnis-Universitas Airlangga \\ Email: achmad-adnan-feb12.web.unair.ac.id \\ Raditya Sukmana \\ Departemen Ekonomi Syariah-Fakultas Ekonomi dan Bisnis-Universitas Airlangga \\ Email: raditya-s@Feb.unair.ac.id
}

\begin{abstract}
This study aims to examine the effect of monetary policy transmission through conventional and sharia systems to the inflation rate in Indonesia from January 2011 to December 2015. The approach used is Vector Error Correction Model (VECM)quantitative method using Eviews 8 program. The data used was secondary data from the official website of Bank Indonesia and the Financial Services Authority (Otoritas Jasa Keuangan/OJK). The result of the research shows that in the long run, conventional monetary policy transmission has an effect on inflation rate in Indonesia, namely the interest rate of Bank Indonesia Certificates which has a positive and significant effect to the inflation rate in Indonesia. Interbank money market variables have negative and significant influence on the inflation rate. While the loan to deposit ratio variable doesn't have any effect on inflation rate. On the sharia side, the results show that in the long run, the sharia monetary policy transmission has an effect on inflation in Indonesia, namely Bank Indonesia Sharia Certificate that has significant negative effect and sharia money market has significant positive effect, whilst finance to deposit ratio doesn't.
\end{abstract}

Keywords: Transmission of sharia and conventional monetary policy, inflation, VECM, vector error correction model.

\section{PENDAHULUAN}

Sejarah membuktikan bahwa hampir keseluruhan negara di dunia mengalami persoalan yang cukup rumit yaitu krisis ekonomi. Diawali dengan terjadinya malapetaka yang besar (the great depressions) pada tahun 1930-an, kemudian disusul dengan terjadinya krisis Amerika Latin pada dekade 1980-an, akhirnya muncul kembali pada krisis moneter di Asia pada ${ }^{[1]} J u r n a l$ ini merupakan bagian dari Skripsi Achmad Adnan Fauzi Wicaksana NIM 041211433077 yang diuji pada tanggal 12 Januari 2018 pertengahan tahun 1997-an. Inflasi didefinisikan sebagai kenaikan tingkat harga secara umum. Definisi itu sebagai kebalikan dari kenaikan harga hanya satu atau dua komoditi saja Pengalaman krisis demi krisis yang menimpa ekonomi dunia dalam satu abad terakhir ini seharusnya telah menyadarkan kepada kita bahwa masalah inflasi telah berkembang menjadi 
Wicaksana, et al/Jurnal Ekonomi Syariah Teori dan Terapan Vol. 5 No. 12 Desember 2018: 10631078; INFLASI DI INDONESIA PADA PERIODE 2011-2015: ANALISIS SERTIFIKAT BANK INDONESIA, SERTIFIKAT BANK INDONESIA SYARIAH, PASAR UANG ANTAR BANK, PASAR UANG ANTAR BANK SYARIAH, FINANCE TO DEPOSIT RATIO DAN LOAN TO DEPOSIT RATIO

persoalan yang semakin kompleks (Triono, 2006).

Jika mau merujuk kepada Al Qur'an, maka akan dijumpai ayat yang memberi informasi tentang akan terjadinya ketidakstabilan atau bahkan kegoncangan ekonomi, jika manusia melakukan kesalahan dalam menjalankan praktik ekonomi. Hal itu dapat disimak dalam QS. Al Baqarah: 275:

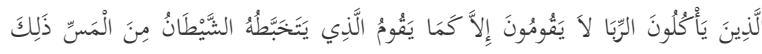

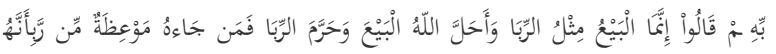

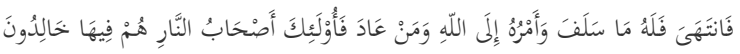

QS. Al Baqarah:275. I'-lażina ya' kuluuna 'Iribāaa yaquumuuna illaa kamaa yaquumu l'-adzii yatakhabbathuhu 'sy-syayțānu mina l'-massi dzaalika bi-annahum qaaluu innamaa l'-bay'u mitslu l'-ribaa wa-ahalla l'laahu l'-bay'a waharrama l'-rribaa faman jaa-ahu maw'izhatun min rabbihi faintahaa falahu maa salafa wa-amruhu ilaa l'-laahi waman 'aada faulaa-ika ash-haabu I'nnaari hum fiihaa khaaliduuna

Artinya: "Orang-orang yang makan (mengambil) ribatidak dapat berdiri melainkan seperti berdirinya orang yang kemasukan syaitan lantaran (tekanan) penyakit gila(2). Keadaan mereka yang demikian itu, adalah disebabkan mereka berkata (berpendapat), sesungguhnya jual beli itu sama dengan riba, padahal Allah telah menghalalkan jual beli dan mengharamkan riba. Orang-orang yang telah sampai kepadanya larangan dari Tuhannya, lalu terus berhenti (dari mengambil riba), maka baginya apa yang telah diambilnya dahulu (sebelum datang larangan); dan urusannya (terserah) kepada Allah. Orang yang kembali (mengambil riba), maka orang itu adalah penghuni-penghuni neraka; mereka kekal di dalamnya."

Menurut Chapra (2000), jika hendak melakukan pengobatan, maka tidak akan ada pengobatan yang efektif kecuali hal itu diarahkan kepada arus utama masalah. Kesalahan yang umumnya dilakukan adalah bahwa pengobatan hanya dilakukan pada gejala saja, bukan secara kausatik (sumber masalah).

Mekanisme transmisi kebijakan moneter di Indonesia yang dilakukan bank Indonesia sebagai otoritas moneter dapat mempengaruhi berbagai kegiatan ekonomi dan keuangan. Perubahan BI Rate mempengaruhi inflasi tersebut disebut sebagai mekanisme transmisi kebijakan moneter. Mekanisme ini menggambarkan tindakan Bank Indonesia melalui perubahan-perubahan instrumen moneter dan target operasionalnya mempengaruhi berbagai variable ekonomi dan keuangan sebelum akhirnya berpengaruh ke tujuan akhir inflasi. Mekanisme tersebut terjadi melalui interaksi antara Bank Sentral, perbankan dan sektor keuangan, serta sektor riil. Perubahan BI Rate mempengaruhi inflasi melalui berbagai jalur, diantaranya jalur suku bunga, jalur kredit, jalur nilai tukar, jalur harga aset, dan jalur ekspektasi. Bernanke dan Gertler menekankan pada sektor kredit (credit channel) sementara Obstfeld and Rogoff memilih untuk menekankan konsep mekanisme transmisi pada kebijakan nilai tukar (Rusydiana, 2009 
Wicaksana, et al/Jurnal Ekonomi Syariah Teori dan Terapan Vol. 5 No. 12 Desember 2018: 10631078; INFLASI DI INDONESIA PADA PERIODE 2011-2015: ANALISIS SERTIFIKAT BANK INDONESIA, SERTIFIKAT BANK INDONESIA SYARIAH, PASAR UANG ANTAR BANK, PASAR UANG ANTAR BANK SYARIAH, FINANCE TO DEPOSIT RATIO DAN LOAN TO DEPOSIT RATIO

Pada jalur suku bunga, perubahan BI Rate mempengaruhi suku bunga deposito dan suku bunga kredit perbankan. Apabila perekonomian sedang mengalami kelesuan, Bank Indonesia dapat menggunakan kebijakan moneter yang ekspansif melalui penurunan suku bunga untuk mendorong aktifitas ekonomi. Perubahan suku bunga BI Rate juga dapat mempengaruhi nilai tukar. Mekanisme ini sering disebut jalur nilai tukar. Kenaikan Bl Rate, sebagai contoh, akan mendorong kenaikan selisih antara suku bunga di Indonesia dengan suku bunga luar negeri. Dengan melebarnya selisih suku bunga tersebut mendorong investor asing untuk menanamkan modal ke dalam instrument-instrumen keuangan di Indonesia seperti SBI karena investor akan mendapatkan tingkat pengembalian yang lebih tinggi. Aliran modal masuk asing ini pada gilirannya akan mendorong apresiasi nilai tukar Rupiah. Apresiasi Rupiah mengakibatkan harga barang impor lebih murah dan barang ekspor di luar negeri menjadi lebih mahal atau kurang kompetitif sehingga akan mendorong impor dan mengurangi ekspor. Turunnya net ekspor ini akan berdampak pada menurunnya pertumbuhan ekonomi dan kegiatan perekonomian.Perubahan suku bunga BI Rate mempengaruhi perekonomian makro melalui perubahan harga aset.

Transmisi kebijakan moneter di Indonesia bisa diselesaikan berdasar 2 konsep yaitu konvensional dan syariah. Konsep konsvensional merupakan konsep pertama. Secara sederhana, operasi moneter syariah adalah operasi moneter yang dilaksanakan sesuai dengan prinsip syariah. Pemenuhan prinsip syariah dipersyaratkan mengingat mitra transaksi (counterparts) yang dihadapi oleh Bank Indonesia dalam operasi moneter syariah adalah perbankan syariah. Jadi, terdapat dua ciri khusus pada operasi moneter syariah. Pertama adalah kesesuaian transaksi yang dilakukan dengan prinsip syariah. Kedua adalah perbankan syariah sebagai mitra transaksi. Sebagai jaminan bahwa transaksi yang dilakukan sesuai syariah, seluruh transaksi operasi moneter syariah yang dilaksanakan Bank Indonesia terlebih dahulu memperoleh fatwa dan atau opini syariah dari Dewan Syariah Nasional-Majelis Ulama Indonesia.Selain dalam rangka implementasi kebijakan moneter, operasi moneter syariah yang dilakukan Bank Indonesia juga memberikan dukungan terhadap stabilitas pasar vang syariah dan pertumbuhan perbankan syariah.

Tujuan dari penelitian ini yaitu: 1) Untuk mengetahui pengaruh SBI, SBIS, PUAB,PUAS, FDR dan LDR pada tingkat inflasi periode 2011-2015, 2) Untuk mengetahui besarnya pengaruh SBI, SBIS, PUAB,PUAS, FDR dan LDR pada tingkat inflasi periode 2011-2015

\section{LANDASAN TEORI}

Konsep Kebijakan Moneter

Menurut pendapat Warjiyo dan Agung (2002), kebijakan moneter 
Wicaksana, et al/Jurnal Ekonomi Syariah Teori dan Terapan Vol. 5 No. 12 Desember 2018: 10631078; INFLASI DI INDONESIA PADA PERIODE 2011-2015: ANALISIS SERTIFIKAT BANK INDONESIA, SERTIFIKAT BANK INDONESIA SYARIAH, PASAR UANG ANTAR BANK, PASAR UANG ANTAR BANK SYARIAH, FINANCE TO DEPOSIT RATIO DAN LOAN TO DEPOSIT RATIO

merupakan bagian integral kebijakan ekonomi makro yang dilakukan dengan pertimbangan siklus kegiatan ekonomi, sifat perekonomian suatu Negara, beserta factor-faktor fundamental/dasar ekonomi lainnya. Juga seperti yang diutarakan Rahardjo dan manurung (2001:359) bahwa kebijakan moneter yang di maksud adalah upaya pengendalian atau mengarahkan perekonomian makro ke kondisi yang di inginkan dengan mengatur jumlah vang beredar.

\section{Kebijakan Moneter Syariah}

Menurut Chapra (2000:12) bank sentral Islam harus bertanggung jawab dalam mengeluarkan vang dengan kerja sama bersama pemerintah, mengusahakan stabilitas internal dan eksternalnya. Stabilitas nilai vang mencerminkan terkontrolnya harga yang pada akhirnya akan mempengaruhi realisasi pencapaian tujuan pembangunan suatu Negara, seperti pemenuhan kebutuhan dasar, pemerataan distribusi, perluasan kesempatan kerja, pertumbuan ekonomi riil yang optimal dan stabilitas ekonomi. Dalam perekonomian Islam menurut Mustafa Edwin (2007:262-265) permintaan akan dana untuk investasi yang berorientasi kepada modal sendiri, merupakan bagian dari permintaan transaksi total dan akan bergantung pada kondisi perekonomian dan laju keuntungan yang diharapkan yang tidak akan ditentukan di depan. Mengingat harapan terhadap keuntungan tidak mengalami fluktuasi harian atau mingguan, permintaan agregat kebutuhan transaksi akan cenderung lebih stabil. Stabilitas yang lebih besar dalam permintaan uang untuk tujuan transaksi akan cenderung mendorong stabilitas yang lebih besar bagi kecepatan peredaran uang dalam suatu fase daur bisnis dalam sebuah perekonomian Islam dan dapat diperkirakan perilakunya secara lebih baik.

\section{Mekanisme Transmisi Kebijakan Moneter Syariah}

Chapra (2000) mengatakan, bahwa kebijakan moneter bertujuan untuk mencapai sosio ekonomi Islam. Antara lain yaitu:

1. Kesejahteraan ekonomi secara luas dengan berlandaskan full employment dengan tingkat pertumbuhan optimum;

2. Keadilan sosio-ekonomi dan pemerataan distribusi pendapatan dan kesejahteraan, salah satunya dapat dilakukan dengan mekanisme zakat yang baik dan benar;

3. Stabilitas nilai vang sehingga benarbenar menjadi medium of exchange yang benar-benar adil dan stabil;

4. Mobilisasi dan investasi modal untuk pembangunan ekonomi yang produktif dengan sistem pembagian yang adil untuk semua pihak yang terlibat;

5. Mewujudkan jasa-jasa lain, seperti pasar primer dan skunder untuk memenuhi kebutuhan akan pendanaan dan keuangan yang non-inflationary untuk pemerintah.

Pengaruh Sertifikat Bank Indonesia (SBI) dan Sertifikat Bank Indonesia Syariah (SBIS) Terhadap Inflasi di Indonesia 
Wicaksana, et al/Jurnal Ekonomi Syariah Teori dan Terapan Vol. 5 No. 12 Desember 2018: 10631078; INFLASI DI INDONESIA PADA PERIODE 2011-2015: ANALISIS SERTIFIKAT BANK INDONESIA, SERTIFIKAT BANK INDONESIA SYARIAH, PASAR UANG ANTAR BANK, PASAR UANG ANTAR BANK SYARIAH, FINANCE TO DEPOSIT RATIO DAN LOAN TO DEPOSIT RATIO

Ketika BI menerbitkan SBI dan SBIS dan menjualnya pada masyarakat akan menyebabkan jumlah vang beredar dimasyarakat berkurang. Menurut Rahardjo dan Manurung (2001: 359), menurunkan Jumlah Uang Beredar (JUB) adalah salah satu target yang ingin dicapai dalam penetapkan kebijakan kontraktif. Kebijakan ini dilakukan pada saat perekonomian berjalan terlalu kuat dan menyebabkan inflasi. Sehingga harapannya ketika JUB berkurang akan menekan permintaan masyarakat akan barang yang merupakan faktor penyebab terjadinya demand pullinflation sehingga tingkat inflasi dapat ditekan.

Pengaruh Pasar Uang Antar Bank (PUAB) dan Pasar Uang Antar Bank Syariah (PUAS) terhadap Inflasi di Indonesia

PUAS sebagai variabel dependen Kebijakan PUAS mengatur bank umum syariah maupun konvensional dapat berinvestasi jangka pendek pada bank umum syariah yang membutuhkan likuiditas dengan menggunakan prinsip mudharabah atau bagi hasil, sedangkan PUAB mengatur bank konvensional dapat berinvestasi jangka pendek pada pada bank umum konvensional yang membutuhkan likuiditas dengan menggunakan suku bunga. Ketika apabila dari perkiraan perhitungan likuiditas maupun dari indikator bagi hasil di PUAS diperkirakan mengalami kelebihan likuiditas, yang diantaranya diindikasikan melalui penurunan sUkU bunga PUAB secara tajam maka diberlakukannya kebijakan OPT Absorbsi. Sedangkan apabila dari perkiraan perhitungan likuiditas maupun dari indikator suku bunga di PUAB diperkirakan mengalami kekurangan likuiditas, yang diantaranya diindikasikan melalui peningkatan sUkU bunga PUAB secara tajam diberlakukannya kebijakan OPT injeksi yang semua diatur dalam pelaksanaan Operasi Moneter Syariah. (www.bi.go.id)

Pengaruh Loan to Deposit Ratio (LDR) dan Finance to Deposit Ratio (FDR) terhadap Inflasi di Indonesia

Menurut Karl dan Fair, suku bunga adalah bunga dari suatu pinjaman yang dibayarkan secara tahunan dalam bentuk persentase pinjaman yang diperoleh dari jumlah bunga yang diterima setiap tahun dibagi dengan jumlah pinjaman. Menurut Miller, RL, dan Vanhoose, sejumlah dana dalam bentuk uang yang diterima oleh kreditor yang merupakan rasio dari bunga terhadap jumlah pinjaman. Sedangkan pengaruh Finance to Deposit Ratio terhadap tingkat Inflasi ialah, tingkat inflasi berpengaruh positif terhadap dana pihak ketiga. Akan tetapi, inflasi yang tinggi akan menyebabkan pendapatan riil masyarakat akan terus turun, sehingga diperkirakan kecenderungan masyarakat untuk menyimpan dananya di bank juga akan menurun (Cahyono, 2009). Dengan demikian, maka hipotesis dalam penelitian ini adalah: $\mathrm{HI}=$ Tingkat inflasi berpengaruh negatif terhadap jumlah deposito mudharabah.

Finance to Deposit ratio yang berbasis Profit-loss sharing berarti keuntungan dan 
Wicaksana, et al/Jurnal Ekonomi Syariah Teori dan Terapan Vol. 5 No. 12 Desember 2018: 10631078; INFLASI DI INDONESIA PADA PERIODE 2011-2015: ANALISIS SERTIFIKAT BANK INDONESIA, SERTIFIKAT BANK INDONESIA SYARIAH, PASAR UANG ANTAR BANK, PASAR UANG ANTAR BANK SYARIAH, FINANCE TO DEPOSIT RATIO DAN LOAN TO DEPOSIT RATIO

atau kerugian yang mungkin timbul dari kegiatan ekonomi/bisnis ditanggung bersamasama. Dalam atribut nisbah bagi hasil tidak terdapat suatu fixed and certain return sebagaimana bunga, tetapi dilakukan profit and loss sharing berdasarkan produktifitas nyata dari produk tersebut (Karim, 2001).

\section{Hipotesis}

Hipotesis yang dapat disimpulkan dalam penelitian ini ialah sebagai berikut:

$H 1$ : SBI, PUAB, LDR berpengaruh secara langsung pada tingkat Inflasi

H2: SBIS,PUAS,FDR berpengaruh langsung pada tingkat Inflasi

H3: SBI, PUAB, LDR berpengaruh secara tidak langsung pada tingkat inflasi

H4: SBIS, PUAS, FDR mempunyai pengaruh secara tidak langsung pada tingkat inflasi

\section{METODE PENELITIAN}

Penelitian ini menggunakan pendekatan kuantitatif deskriptif yakni diperuntukkan menjawab rumusan masalah serta tujuan dari penelitian yakni pengaruh transmisi moneter syariah pada system perbankan syariah terhadap inflasi di Indonesia. Pendekatan penelitian yang dipakai dalam penelitian ini ialah metode Kuantitatif. Metode kuantitatif ialah metode penelitian terstruktur dan mengkuantifikasikan data untuk dapat digeneralisasi (Anshori dan Iswati, 2009:13). Pendekatan kuantitatif merupakan pengujian hipotesis dengan data yang terukur sehingga dapat diperoleh parameter dari pengaruh perubahan suatu variabel ekonomi terhadap variabel ekonomi yang lainnya serta penjelasanpenjelasan dari asumsi pada ilmu ekonomi. Tujuan metode penelitian kuantitatif adalah menampilkan pengaruh antar variabel, mencari teori, mencari generalisasi yang mempunyai nilai prediktif (Sugiyono,2012:14). Pendekatan kuantitatif dilakukan dengan memakai model ekonometrika gabungan analisa matematis, teori ekonomi dan statistik.

\section{Jenis Data}

Jenis data yang digunakan dalam penelitian ini adalah data ratio sekunder yang berupa data runtut waktu (time series) yang merupakan sekumpulan observasi dalam rentang waktu tertentu. Data time series yang digunakan mulai dari tahun 2011 hingga 2015. Sumber data yang dipakai didapat melalui statistic ekonomi dan keuangan Indonesia (SEKI) yang dikeluarkan oleh Bank Indonesia yang merupakan populasi dari peneltian ini dan sampelnya ialah data keuangan SBI, SBIS, PUAB, PUAS, LDR, FDR pada tahun 2011-2015 yang bersumber dari SEKI Bank Indonesia dan SEKI OJK.

\section{Populasi dan Sampel}

Populasi dalam penelitian ini adalah tingkat $S B I$, tingkat $S B I S$, tingkat PUAB, tingkat PUAS, tingkat LDR, tingkat FDR dan tingkat inflasi di Indonesia. Metode pemilihan sample yang digunkan pada penelitian ini adalah teknik sampel jenuh (sensus, yaitu penentuan sample yang secara keseluruhan berasal dari populasi dengn pertimbangan elemen-elemen populasi relatif sedikit kedua kriteria pada populasi 
Wicaksana, et al/Jurnal Ekonomi Syariah Teori dan Terapan Vol. 5 No. 12 Desember 2018: 10631078; INFLASI DI INDONESIA PADA PERIODE 2011-2015: ANALISIS SERTIFIKAT BANK INDONESIA, SERTIFIKAT BANK INDONESIA SYARIAH, PASAR UANG ANTAR BANK, PASAR UANG ANTAR BANK SYARIAH, FINANCE TO DEPOSIT RATIO DAN LOAN TO DEPOSIT RATIO

tersebut, maka tingkat SBI, SBIS, PUAB, PUAS,

LDR, FDR dan Tingkat inflasi yang menjadi sample penelitian ini adalah:
a. Tingkat SBI pada tahun 2011-2015
b. Tingkat SBIS pada tahun 2011-2015
C. Tingkat PUAB pada tahun 2011-2015
d. Tingkat PUAS pada tahun 2011-2015
e. Tingkat LDR pada tahun 2011-2015
f. Tingkat FDR pada tahun 2011-2015
g. Tingkat Inflasi pada tahun 201 1-2015

\section{Teknik Analisis}

Metode yang digunakan dalam penelitian ini adala metode Vector Error Correction Model (VECM). VECM merupakan bentuk VAR yang terestriksi. Restriksi tambahan ini harus diberikan karena keberadaan bentuk data yang tidak stasioner namun terkointegrasi. VECM kemudian memanfaatkan informasi restriksi kointegrasi kedalam spesiikasinya, oleh karena itulah VECM sering disebut sebagai design VAR bagi series nonstasioner yang memiliki hubungan kointegrasi. Dalam permodelan VECM asumsi awal yang harus dipenuhi ialah bahwa semua variabel independen harus stasioner.

Hal ini ditandai dengan semua variabel sisaan bersifat white noise, yaitu memiliki rataan nol, ragam konstan, dan di antara variabel tidak bebas tidak terdapat korelasi. Uji kestasioneran data dapat dilakukan melalui pengujian terhadap ada atau tidaknya unit root dalam variabel dengan uji Augmented Dickey Fuller (ADF), adanya unit root akan menghasilkan persamaan atau model regresi yang lancung (spurious). Pendekatan yang dilakukan untuk mengatasi persamaan regresi lancung tersebut adalah dengan melakukan diferensiasi atas variabel endogen dan eksogennya, sehingga diperoleh variabel yang stasioner dengan derajat I(n) (Ajija, 2011)

\section{HASIL DAN PEMBAHASAN}

Hasil Estimasi VECM

Tabel 1. Hasil Uji VECM Konvensional Jangka Panjang

\begin{tabular}{|c|c|}
\hline COINTEGRATING EQ & COINTEQ 1 \\
\hline IHK(-1) & 1.00000 \\
\hline & 0.090397 \\
LDR(-1) & $(0.07308)$ \\
& {$[1.23696]$} \\
\hline & 7.687694 \\
PUAB(-1) & $(1.05203)$ \\
& {$[7.30750]$} \\
\hline & -7.940233 \\
SBI(-1) & $(1.01108)$ \\
& {$[-7.85320]$} \\
\hline C & -7.093728 \\
\hline
\end{tabular}

Dari hasil kointegrasi diatas menunjukkan data yang telah dianalisis merupakan data yang telah terkointegrasi, maka dapat disimpulkan bahwa model tersebut dapat dipakai untuk mengetahui tingkah laku jangka pendek dan jangka panjang. Dapat disimpulkan bahwa pada jangka panjang tingkat Loan to Deposit Ratio (LDR) menunjukkan bahwa pada jangka panjang tidak berpengaruh secara signifikan terhadap $\mathbb{H K}$ pada tingkat signifikan 5\%. Hasil ini diperoleh karena dengan nilai koefisien Loan to Deposit Ratio sebesar -0.90397 dan nilai dari t-statistik sebesar [1.23696] yang lebih kecil dari pada nilai t-tabel sebesar [2.00575]. dapat diketahui jika tingkat Loan to Deposit Ratio 
Wicaksana, et al/Jurnal Ekonomi Syariah Teori dan Terapan Vol. 5 No. 12 Desember 2018: 10631078; INFLASI DI INDONESIA PADA PERIODE 2011-2015: ANALISIS SERTIFIKAT BANK INDONESIA, SERTIFIKAT BANK INDONESIA SYARIAH, PASAR UANG ANTAR BANK, PASAR UANG ANTAR BANK SYARIAH, FINANCE TO DEPOSIT RATIO DAN LOAN TO DEPOSIT RATIO

meningkat sebesar $5 \%$ maka $I H K$ akan menurun sebesar $0.90397 \%$.

Pasar Uang Antar Bank (PUAB) menunjukkan bahwa dalam jangka panjang berpengaruh secara signifikan teradap IHK pada tingkat signifikan $5 \%$. Hasil tersebut diperoleh karena dengan nilai koefisien PUAB sebesar -7.687694 dan nilai †statistik sebesar [7.30750] yang lebih besar dari nilai t-tabel sebesar [2.00575]. dapat diketaui jika tingkat suku bunga pasar uang antar bank meningkat sebesr $5 \%$ maka IHK akan menurun sebesar 7.687694\%.

Sertifikat Bank Indonesia menunjukkan bahwa pada jangka panjang berpengaruh secara signifikan terhadap IHK pada tingkat $5 \%$. Hasil tersebut diperoleh karena dengan nilai koefisien SBI sebesar 7.940233 dan nilai dari t-statistik sebesar [7.85320] yang lebih besar daripada t-tabel sebesar [2.00575]. maka dapat diketahui bahwa pada saat tingkat imbal hasil SBI meningkat sebesar 5\% maka IHK akan meningkat sebesar $7.940233 \%$.

Tabel 2. Hasil Uji VECM Syariah Jangka

Panjang

\begin{tabular}{|c|c|}
\hline COINTEGRATING EQ & COINTEQ I \\
\hline IHK(-1) & 1.00000 \\
\hline FDR(-1) & -0.149910 \\
& $(0.12465)$ \\
& {$[-1.20267]$} \\
\hline PUAS(-1) & -10.97600 \\
& $(2.15976)$ \\
& {$[-5.08206]$} \\
\hline SBIS(-1) & 7.957543 \\
& $(1.73170)$ \\
& {$[4.59521]$} \\
\hline C & 21.17257 \\
\hline
\end{tabular}

Hasil estimasi VECM dalam jangka panjang dapat disimpulkan bahwa dalam jangka panjang tingkat Finance to Deposit Ratio tidak berpengaruh secara signifikan terhadap $I H K$ pada tingkat signifikan $5 \%$. Hasil tersebut diperoleh karena dengan nilai koefisien FDR sebesar 0.0149910 dan nilai tstatistik sebesar [-120267] yang lebih kecil daripada nilai t-tabel sebesar [2.00575]. dapat diketahui jika ketika tingkat FDR meningkat sebesar 5\% maka IHK akan meningkat sebesar $0.0149910 \%$ Pasar Uang Antar Bank Syariah (PUAS) menunjukkan bahwa pada jangka panjang berpengaruh secara signifikan terhadap IHK pada tingkat signifikan $5 \%$. Hasil tersebut diperoleh karena dengan nilai koefisien PUAS sebesar 10.97600 dan nilai t-statistik sebesar [5.08206] yang lebih besar daripada nilai ttabel sebesar [2.00575]. dapat diketahui bahwa jika Tingkat suku bunga PUAS meningkat sebesar 5\% maka IHK akan meningkat sebesar $10.97600 \%$ Sertifikat Bank Indonesia Syariah (SBIS) menunjukkan bahwa pada jangka panjang berpengaruh secara signifikan terhadap IHK pada tingkat $5 \%$. Hasil tersebut diperoleh karena dengan nilai koefisien SBIS sebesar -7.957543 dan nilai dari t-statistik sebesar [4.59521] yang lebih besar daripada t-tabel sebesar [2.00575]. maka dapat diketahui bahwa pada saat tingkat imbal hasil SBIS meningkat sebesar $5 \%$ maka IHK akan menurun sebesar $7.957543 \%$. 
Wicaksana, et al/Jurnal Ekonomi Syariah Teori dan Terapan Vol. 5 No. 12 Desember 2018: 10631078; INFLASI DI INDONESIA PADA PERIODE 2011-2015: ANALISIS SERTIFIKAT BANK INDONESIA, SERTIFIKAT BANK INDONESIA SYARIAH, PASAR UANG ANTAR BANK, PASAR UANG ANTAR BANK SYARIAH, FINANCE TO DEPOSIT RATIO DAN LOAN TO DEPOSIT RATIO

Tabel 3. Hasil Uji VECM Konvensional \& Syariah Jangka Pendek

\begin{tabular}{|c|c|c|c|}
\hline CointEq 1 & $\begin{array}{c}-0.031084 \\
(0.08290) \\
{[-0.37498]}\end{array}$ & CointEql & $\begin{array}{l}0.010034 \\
(0.03426) \\
{[0.29284]}\end{array}$ \\
\hline $\mathrm{D}(\mathrm{IHK}(-2))$ & $\begin{array}{l}-0.068847 \\
(0.19166) \\
{[-0.35921]}\end{array}$ & $\mathrm{D}\left(\mathrm{IHK} \_(-1)\right)$ & $\begin{array}{l}0.338110 \\
(0.15181) \\
{[2.22725]}\end{array}$ \\
\hline D(INT_LDR_(-2)) & $\begin{array}{l}-0.002677 \\
(0.17280) \\
{[-0.01549]}\end{array}$ & $\mathrm{D}\left(\mathrm{PLS} \_F D R \_(-1)\right)$ & $\begin{array}{l}0.036081 \\
(0.05128) \\
{[0.70356]}\end{array}$ \\
\hline $\mathrm{D}(\mathrm{P} \cup A B(-2))$ & $\begin{array}{l}0.260597 \\
(0.42537) \\
{[0.61263]}\end{array}$ & D(PUAS(-1)) & $\begin{array}{l}-0.028509 \\
(0.29902) \\
{[-0.09534]}\end{array}$ \\
\hline $\mathrm{D}(\mathrm{SBI}(-2))$ & $\begin{array}{c}-0.223787 \\
(0.50271) \\
{[-0.44516]}\end{array}$ & $D(S B I S(-1))$ & $\begin{array}{r}-0.025669 \\
(0.41610)\end{array}$ \\
\hline
\end{tabular}

Pada tabel menunjukkan tidak ada satupun variabel dalam jangka pendek yang berpengaruh signifikan. Hal ini dikarenakan tidak ada satupun nilai tstatistik dari seluruh variabel yang lebih besar daripada nilai t-tabel sebesar [2.00575]. Estimasi VECM sendiri tidak banyak menjelaskan pergerakan dinamis dari model VECM. Pergerakan dinamis dapat dilihat melalui Impulse Response dan Variance Decomposition. Impulse Response menunjukkan seberapa lama pengaruh adanya shock variabel yang satu terhadap variabel lainnya serta untuk melacak respon dari variabel endogen terhadap shock variabel lainnya. Variance Decomposition berguna untuk memprediksi kontribusi persentase varian setiap variabel karena adanya perubahan atau shock pada variabel tertentu (Widarjono, 2007:353-356).

Hasil Analisis Impulse Response Function.

Dalam penelitian ini, Impulse Response akan lebih focus pada pembahasan respon variabel Indeks Harga Konsumen (IHK) terhadap shock yang ditimbulkan oleh variabel $S B I, S B I S, P \cup A B, P \cup A S, L D R$, dan FDR. Grafik yang ditunjukkan oleh Impulse Response merupakan perwakilan dari satu kuartal. Sumbu vertical pada grafik Impulse Response merupakan penggambaran perubahan suatu variabel yang dipengaruhi oleh shock yang ditimbulkan oleh variable tertentu, dinyatakan satuan standard deviasi (SD)

Impulse response menunjukkan secara keseluruhan IHK merespon variabel 
Wicaksana, et al/Jurnal Ekonomi Syariah Teori dan Terapan Vol. 5 No. 12 Desember 2018: 10631078; INFLASI DI INDONESIA PADA PERIODE 2011-2015: ANALISIS SERTIFIKAT BANK INDONESIA, SERTIFIKAT BANK INDONESIA SYARIAH, PASAR UANG ANTAR BANK, PASAR UANG ANTAR BANK SYARIAH, FINANCE TO DEPOSIT RATIO DAN LOAN TO DEPOSIT RATIO

Loan to deposit ratio. Periode pertama menunjukkan bahwa IHK merespon shock dari variabel Loan to deposit ratio. Shock ini ditandai dengan positif yang menandakan bahwa adanya kenaikan dari variabel LDR sebesar 1 SD direspon dengan kenaikan IHK 0.169699 SD. kemudian pada periode selanjutnya yaitu periode kedua IHK merespons shock dari LDR secara positif yang menimbulkan kenaikan 1 SD. kenaikan LDR sebesar 1 SD akan direspons positif dengan peningkatan IHK sebesar 0.199034 SD. Respons dari IHK teradap Shock yang ditimbulkan dari variabel PUAB pada periode pertama belum menunjukkan adanya perubahan, namun pada periode kedua timbul respons positif dengan adanya kenaikan 1 SD dari shock dari variabel PUAB sebesar 0.021882 SD hingga period ketiga. Periode berikutnya yaitu periode keempat menunjukkan bahwa IHK merespon shock variabel PUAB secara negatif. Penambahan PUAB sebesar 1 SD akan direspon dengan penurunan IHK sebesar -0.064511 SD.

Hasil pengujian Impulse response variabel PUAB secara keseluruhan IHK merespon shock variabel Sertifikat Bank Indonesia secara fluktuatif. Pada periode pertama IHK belum merespon shock dari SBI. Pada periode ketiga IHK merespons shock dari SBI secara negatif. Penurunan 1 SD SBI akan berpengaruh menurunkan IHK sebesar -0.079297. berikutnya pada periode keenam hingga periode akhir IHK merespons variabel SBI secara positif. Penambahan SBI sebesar 1 SD akan direspons dengan Peningkatan IHK pada angka 0.034194. Hasil pengujian Impulse Response variabel

Respons IHK pada shock dari variabel Finance to Deposit ratio yang dapat disimpulkan fluktuatif. Pada awal periode IHK belum merespons shock variabel finance to deposit ratio. Pada periode kedua IHK menunjukkan respons dari shock variabel finance to deposit ratio secara positif. Penambahan 1 SD pada variabel FDR akan direspons dengan peningkatan pada variabel IHK sebesar 0.086361 SD. Pada periode berikutnya yaitu periode ketiga hingga akhir periode menunjukkan bahwa IHK merespons variabel FDR secara positif. Setiap penambahan variabel FDR sebesar 1 SD maka akan direspn dengan peningkatan IHK sebesar 0.105461 SD.

Hasil Impulse response dari shock variabel Pasar Uang Antar Bank Syariah yang secara keseluruhan direspon secara negatif. Pada pariode awal IHK belum merespon variabel PUAS. Pada periode kedua sampai periode ketiga menunjukkan bahwa IK merespon variabel PUAS. Penambahan 1 SD pada variabel PUAS akan direspons dengan variabel IHK sebesar -0.061380 SD. pada periode berikutnya yaitu periode keempat hingga akhir periode IHK tetap merespons shock dari variabel PUAS secara negatif. Penambahan 1 SD oleh variabel PUAS akan direspons oleh penurunan IHK sebesar -0.063515 SD.

Hasil Impulse response dari shock variabel Sertifikat Bank Indonesia Syariah secara keseluruhan terhadap IHK secara positif. Pada awal periode IHK belum 
Wicaksana, et al/Jurnal Ekonomi Syariah Teori dan Terapan Vol. 5 No. 12 Desember 2018: 10631078; INFLASI DI INDONESIA PADA PERIODE 2011-2015: ANALISIS SERTIFIKAT BANK INDONESIA, SERTIFIKAT BANK INDONESIA SYARIAH, PASAR UANG ANTAR BANK, PASAR UANG ANTAR BANK SYARIAH, FINANCE TO DEPOSIT RATIO DAN LOAN TO DEPOSIT RATIO

merespon shock variabel SBIS. Namun pada

periode kedua hingga akhir, IHK merespon variabel SBIS secara positif. Penambahan 1 SD pada variabel SBIS akan direspon dengan meningkatnya IHK Sebesar 0.025470 SD.

\section{Hasil Analisis Variance Decomposition}

Variance decomposition atau dapat disebut dengan forecast error variance decomposition merupakan perangkat dari model VAR yang akan memisahkan variasi sejumlah variabel yang diestimasikan menjadi komponen shock atau menjadi variabel innovation dan dengan asumsi bahwa variabel-variabel innovation tidak saling berkorelasi. Variance decomposition akan memberikan informasi mengenai proporsi dari pergerakan pengaruh shock pada sebuah variabel terhadap shock variabel lainnya pada periode sekarang dan yang akan datang.

Penelitian ini menggunakan hasil variance decomposition yang lebih difokuskan pada kontribusi shock dari variabel-variabel Sertifikat Bank Indonesia, Sertifikat Bank Indonesia Syaria, Pssar Uang Antar Bank, Loan to deposit ratio, dan Finance to deposit Ratio terhadap tingkat Inflasi di Indonesia. Hasil dari variance decomposition dapat dilihat pada tabel di bawah ini:

Tabel 4. Hasil Uji Variance Decomposition Sertifikat Bank Indonesia (SBI). Pasar Uang Antar Bank (PUAB), Dan Loan To Deposit Ratio (LDR) Terhadap Tingkat Inflasi

\begin{tabular}{|c|c|c|c|c|c|}
\hline Prd & S.E & IHK & LDR & PUAB & SBI \\
\hline 1 & 0.883725 & 100.0000 & 0.000000 & 0.000000 & 0.000000 \\
2 & 1.516230 & 98.68756 & 1.252650 & 0.006327 & 0.053461 \\
3 & 1.975752 & 98.03889 & 1.752551 & 0.015992 & 0.192569 \\
4 & 2.325314 & 97.98584 & 1.741307 & 0.088512 & 0.184345 \\
5 & 2.610205 & 98.04750 & 1.557460 & 0.247412 & 0.147628 \\
6 & 2.866173 & 98.12708 & 1.369087 & 0.380135 & 0.123696 \\
7 & 3.107341 & 98.17046 & 1.213272 & 0.505611 & 0.110655 \\
8 & 3.335065 & 98.18684 & 1.088559 & 0.620536 & 0.104063 \\
9 & 3.550159 & 98.19546 & 0.988714 & 0.715757 & 0.100068 \\
10 & 3.753967 & 98.19798 & 0.907459 & 0.796764 & 0.097794 \\
\hline
\end{tabular}

Tabel 5. Hasil Uji Variance Decomposition Sertifikat Bank Indonesia Syariah (SBIS), Pasar Uang

Antar Bank Syariah (PUAS), Dan Finance To Deposit Ratio (FDR) Terhadap Tingkat Inflasi

\begin{tabular}{|c|c|c|c|c|c|}
\hline Prd. & S.E & IHK & FDR & PUAS & SBIS \\
\hline & & & & & \\
1 & 0.850687 & 100.0000 & 0.000000 & 0.000000 & 0.000000 \\
2 & 1.438070 & 99.50389 & 0.360640 & 0.128161 & 0.007307 \\
3 & 1.914312 & 99.36247 & 0.446335 & 0.175132 & 0.016065 \\
4 & 2.316145 & 99.29093 & 0.496027 & 0.192220 & 0.020825 \\
5 & 2.665038 & 99.24617 & 0.527137 & 0.202448 & 0.024242 \\
6 & 2.975681 & 99.21858 & 0.546792 & 0.208076 & 0.026557 \\
7 & 3.257669 & 99.19947 & 0.560587 & 0.211738 & 0.028202 \\
8 & 3.517406 & 99.18572 & 0.570594 & 0.214275 & 0.029414
\end{tabular}


Wicaksana, et al/Jurnal Ekonomi Syariah Teori dan Terapan Vol. 5 No. 12 Desember 2018: 10631078; INFLASI DI INDONESIA PADA PERIODE 2011-2015: ANALISIS SERTIFIKAT BANK INDONESIA, SERTIFIKAT BANK INDONESIA SYARIAH, PASAR UANG ANTAR BANK, PASAR UANG ANTAR BANK SYARIAH, FINANCE TO DEPOSIT RATIO DAN LOAN TO DEPOSIT RATIO

\begin{tabular}{|c|c|c|c|c|c|}
9 & 3.759342 & 99.17535 & 0.578174 & 0.216141 & 0.030335 \\
10 & 3.986658 & 99.16727 & 0.584098 & 0.217577 & 0.031056 \\
\hline
\end{tabular}

Hasil Variance decomposition kedua tabel menunjukkan bahwa pada periode pertama dapat disimpulkan tiap tiap variabel di atas belum memberikan kontribusi terhadap variansi perubahan tingkat Inflasi (IHK). Pada periode pertama sebesar 100\% variabel Tingkat Inflasi (IHK). Pada periode berikutnya sampai periode 10 masing-masing variabel mulai memberikan dampak variansi perubahan Tingkat Inflasi (IHK).

Kontribusi shock yang diberikan oleh tingkat Loan to deposit ratio terhadap IHK pada periode kedua sebesar 1.252650\%, kemudian meningkat pada periode ketiga sebesar $1.752551 \%$. selanjutnya pada periode keempat hingga periode terakhir kontribusi shock yang diberikan oleh tingkat LDR menurun sampai periode akhir sebesar $0.907459 \%$. Kontribusi shock yang diberikan oleh tingkat Pasar vang antar bank (PUAB) pada periode kedua sebesar $0.006327 \%$. shock yang diberikan pada periode ketiga meningkat sebesar $\quad 0.015992 \%$. meningkatnya kontribusi shock ini terjadi hingga periode terakhir sebesar $0.796764 \%$.

Kemudian pada variabel tingkat suku bunga Sertifikat bank Indonesia (SBI) memberikan kontribusi shock terhadap IHK pada periode kedua sebesar $0.053461 \%$. Ialu pada periode ketiga meningkat menjadi sebesar $0.192569 \%$, namun pada periode keempat menurun menjadi sebesar 0.184345 . penurunan kontribusi shock variabel SBI ini terjadi hingga periode terakhir yaitu sebesar $0.097794 \%$. Kontribusi shock yang diberikan oleh tingkat Finance to deposit ratio (FDR) terhadap IHK pada periode kedua sebesar $0.360640 \%$, kemudian meningkat pada periode ketiga sebesar $0.446335 \%$. meningkatnya kontribusi shock variabel (FDR) ini terjadi hingga periode akhir yaitu sebesar $0.584098 \%$.

Kemudian pada Variabel pasar vang antar bank syariah (PUAS) memberikan kontribusi shock terhadap IHK pada periode kedua sebesar $0.128161 \%$, lalu meningkat pada periode ketiga sebesar $0.175132 \%$. pada periode keempat hingga periode akhir tetap meningkat hingga pada periode kesepuluh sebesar $0.217577 \%$. Kontribusi shock yang diberikan oleh tingkat suku bunga sertifikat bank Indonesia syariah (SBIS) terhadap IHK pada periode kedua sebesar $0.007307 \%$. angka pada periode kedua meningkat di periode ketiga sebesar $0.016065 \%$. pada periode keempat meningkat kembali sebesar $0.020825 \%$ dan terus terjadi peningkatan besaran shock variabel SBIS hingga periode kesepuluh sehingga mencapai angka $0.031056 \%$ /

\section{Pengujian Hipotesis}

Berdasarkan hasil analisis pada model VECMyang telah dijelaskan pada bab sebelumnya, maka pembuktian hipotesis yang didapat dari hasil uji statistic dalam model VECM diperoleh bahwa terdapat hubungan yang signifikan dalam jangka 
Wicaksana, et al/Jurnal Ekonomi Syariah Teori dan Terapan Vol. 5 No. 12 Desember 2018: 10631078; INFLASI DI INDONESIA PADA PERIODE 2011-2015: ANALISIS SERTIFIKAT BANK INDONESIA, SERTIFIKAT BANK INDONESIA SYARIAH, PASAR UANG ANTAR BANK, PASAR UANG ANTAR BANK SYARIAH, FINANCE TO DEPOSIT RATIO DAN LOAN TO DEPOSIT RATIO

panjang dan jangka pendek. Penelitian ini mengindikasikan bahwa terdapatnya pengaruh variabel eksogen terhadap variabel endogen yang digunakan pada penelitian ini berpengaruh secara signifikan dalam jangka panjang. Tingkat imbal hasil SBI , Tingkat imbal hasil SBIS, Pasar vang antar bank, dan Pasar vang antar bank syariah dalam jangka panjang berpengaruh secara signifikan dalam mempengaruhi Tingkat Inflasi (IHK).

\section{Pembahasan}

Hasil pengolahan data menggunakan analisis VECM dapat diketahui terdapatnya perilaku dari variabel Sertifikat Bank Indonesia (SBI), Sertifikat Bank Indonesia Syariah (SBIS), Pasar Uang Antar Bank (PUAB), Pasar Uang Antar Bank Syariah (PUAS), Loan to Deposit Ratio (LDR), dan Finance to deposit Ratio sehingga dapat dianalisis dan pembahasan. Variabelvariabel tersebut mempengaruhi tingkat inflasi yang disebut IHK. Hasil yang ditunjukkan akan dijelaskan secara rinci antara pertentangan fakta yang ada berdasarkan teori-teori yang sesuai untuk menjelaskan korelasi tersebut.

Pokok pembahasan dalam penelitian ini lebih dipusatkan untuk mengetahui pengaruh yang ditimbulkan oleh

variabel Sertifikat Bank Indonesia (SBI), Sertifikat Bank Indonesia Syariah (SBIS), Pasar Uang Antar Bank (PUAB), Pasar Uang Antar Bank Syariah (PUAS), Loan to Deposit Ratio $(L D R)$, dan Finance to deposit Ratio terhadap tingkat inflasi (IHK) dalam jangka panjang, penelitian ini juga membahas tentang respons variabel variabel Sertifikat Bank Indonesia (SBI), Sertifikat Bank Indonesia Syariah (SBIS), Pasar Uang Antar Bank (PUAB), Pasar Uang Antar Bank Syariah (PUAS), Loan to Deposit Ratio (LDR), dan Finance to deposit Ratio terhadap IHK di Indonesia. Penelitian ini juga membahas variance decomposition dari variabel Sertifikat Bank Indonesia (SBI), Sertifikat Bank Indonesia Syariah (SBIS), Pasar Uang Antar Bank (PUAB), Pasar Uang Antar Bank Syariah (PUAS), Loan to Deposit Ratio (LDR), dan Finance to deposit Ratio terhadap IHK di Indonesia.

\section{Pengaruh Suku Bunga Sertfiikat Bank Indonesia terhadap inflasi}

Factor yang mempengaruhi IHK dalam penelitian ini salah satunya ialah variabel Sertifikat Bank Indonesia. Pada hasil Impulse Response terlihat bahwa shock variabel SBI cenderung di respon secara meningkat pada tiga periode awal, namun pada periode berikutnya hingga akhir cenderung menurun. Respons yang ditunjukkan oleh IHK akibat dari shock variabel SBI memiliki tren positif, sehingga kenaikan SBI akan direspon dengan adanya peningkatan IHK. Peningkatan IHK menunjukkan peningkatan pada tingkat inflasi di Indonesia. Dalam jangka panjang menunjukkan bahwa variabel imbal hasil SBI berpengaruh signifikan dan positif terhadap tingkat inflasi pada jangka panjang, namun pada jangka pendek tidak signifikan dan positif. Hal ini tidak sesuai dengan teori ekonomi makro dimana jika tingkat imbal hasil atau suku bunga meningkat maka akan menyerap 
Wicaksana, et al/Jurnal Ekonomi Syariah Teori dan Terapan Vol. 5 No. 12 Desember 2018: 10631078; INFLASI DI INDONESIA PADA PERIODE 2011-2015: ANALISIS SERTIFIKAT BANK INDONESIA, SERTIFIKAT BANK INDONESIA SYARIAH, PASAR UANG ANTAR BANK, PASAR UANG ANTAR BANK SYARIAH, FINANCE TO DEPOSIT RATIO DAN LOAN TO DEPOSIT RATIO

jumlah vang beredar dan menurunkan inflasi, sebaliknya jika suku bunga turun, maka inflasi akan meningkat pula.

Pengaruh Pasar Uang Antar Bank terhadap Inflasi

Dalam penelitian ini pengaruh suku bunga Pasar Uang Antar Bank pada tingkat inflasi dapat dilihat melalui hasil Impulse response terlihat kontribusi shock dari PUAB terhadap inflasi cenderung menurun, sehingga dapat ditarik kesimpulan bahwa jika suku bunga PUAB naik maka IHK akan menurun. Penurunan IHK menunjukkan penurunan pada tingkat inflasi di Imdonesia.

Dalam jangka panjang menunjukkan bahwa variabel PUAB berpengaruh signifikan dan negatif, namun pada jangka pendeknya tidak signifikan dan positif. Hal ini sesuai dengan pernyataan oleh Bank Indonesia pada situs resmi (bi.go.id), bahwa sasaran operasional kebijakan moneter dicerminkan pada perkembangan sukU bunga Pasar Uang Antar Bank (PUAB). Pergerakan disuku bunga tersebut diharapkan akan diikuti oleh perkembangan di suku bunga deposito, dan pada gilirannya suku bunga kredit perbankan. Sehingga inflasi akan terkendali.

Pengaruh Loan to Deposit Ratio terhadap inflasi

Pada penelitian ini juga menggunakan variabel Loan to Deposit Ratio yang pengaruhnya terhadap inflasi diteliti pada tulisan ini. Hasil estimasi VECM menunjukkan bahwa variabel LDR mempunyai tren negative dan tidak signifikan pada jangka pendek dan jangka panjang. Pada uji impulse response, variabel ini menunjukkan kontribusi shock terhadap tingkat inflasi secara fluktuatif, pada periode awal menunjukkan, hal ini ditunjukkan naik turunnya besaran nilai shock yang diberikan ole variabel LDR ini, dan tetap memberikan kontribusi positif dalam mempengaruhi naiknya tingkat inflasi.

\section{Pengaruh Sertifikat Bank Indonesia Syariah terhadap inflasi}

Variabel selanjutnya ialah Imbal hasil Sertifikat Bank Indonesia Syariah (SBIS) yang dimana variabel ini termasuk berubungan dengan variabel IHK. Pada estimasi VECM yang tela dilakukan, variabel SBIS pada jangka panjang bersifat negative signifikan, berbeda pada jangka pendek yang negative namun tidak signifikan. Jika suku bunga SBIS meningkat maka akan menyerap dana likuiditas pada bank yang berlebih dan menyebabkan menyerap vang beredar pada masyarakat dan akan menurunkan tingkat inflasi.

\section{Pengaruh Pasar Uang Antar Bank Syariah terhadap Inflasi}

Dalam penelitian ini pengaruh variabel Pasar Uang Antar Bank Syariah (PUAS) dapat dilihat melalui analisis hasil estimasi VECM yang menunjukkan adanya signifikansi pada jangka panjang secara positif pada jangka panjang dan jangka pendek juga secara positif. Hal ini di ikuti dengan hasil Impulse response yang memberikan kontribusi shock yang meningkat dari periode awal hingga akhir 
Wicaksana, et al/Jurnal Ekonomi Syariah Teori dan Terapan Vol. 5 No. 12 Desember 2018: 10631078; INFLASI DI INDONESIA PADA PERIODE 2011-2015: ANALISIS SERTIFIKAT BANK INDONESIA, SERTIFIKAT BANK INDONESIA SYARIAH, PASAR UANG ANTAR BANK, PASAR UANG ANTAR BANK SYARIAH, FINANCE TO DEPOSIT RATIO DAN LOAN TO DEPOSIT RATIO

yang menunjukkan variabel ini memicu naiknya tingkat inflasi.

Maka PUAS disini tidak mampu memenuhi harapan sebagai salah satu instrumen kebijakan moneter untuk menekan tingkat inflasi. Harapannya Bank Indonesia dapat menggunakan apa yang disebut dengan diskonto rate untuk mempengaruhi sUkU bunga PUAS dalam menekan tingkat inflasi. Diskonto rate bagi Bank Umum merupakan biaya untuk pinjaman yang diberikan oleh Bank Sentral, sehingga gairah Bank Umum untuk meminjam mengecil, akibatnya kemampuan Bank Umum memberikan pinjaman kepada masyarakat juga semakin kecil, yang menyebabkan rendahnya daya beli masyarakat dan pada akhirnya mengurangi tekanan tingkat inflasi. Salah satu penyebab ketidak mampuan PUAS menekan Tingkat inflasi yaitu melihat fenomena yang terjadi di Indonesia pada masa dilakukannya penelitian ini adalah terjadi pengurangan subsidi dengan menaikan harga BBM. Untuk menjaga tingkat inflasi karena pengaruh kenaikan harga BBM bersubsidi tidak hanya dengan cara menaikkan suku bunga acuan (B) Rate). BI Rate tidak terlalu banyak membantu, bahkan justru berpotensi menaikkan suku bunga kredit yang akan menghambat laju pertumbuhan ekonomi yang sudah relatif rendah untuk ukuran Indonesia, sehingga PUAS juga kurang berpengaruh untuk menekan tingkat pertumbuhan Inflasi.
Pengaruh Finance to Deposit Ratio terhadap Inflasi

Variabel terakhir adalah Finance to Deposit Ratio dimana variabel ini mempunyai pengaruh yang dapat dilihat melalui analisis hasil estimasi VECM secara positif namun tidak signifikan, begitu pula pada jangka pendek. Pada hasil Impulse response menunjukkan adanya kontribusi shock variabel FDR terhadap IHK secara positif, yang menunjukkan peningkatan besaran shock dari awal periode hingga akhir periode. Dapat ditarik kesimpulan bahwa variabel ini memicu naiknya tingkat inflasi. Perilaku suku bunga (konvensional) dan bagi hasil (Syariah) ditunjukkan senada oleh perilaku kredit (LOAN) konvensional dan pembiayaan (FINC) Syariah, karena kredit dipengaruhi oleh suku bunganya, sedangkan pembiayaan dipengaruhi oleh bagi hasilnya, sehingga kreditberdampak negatif terhadap inflasi maupun output, sedangkan pembiayaanberdampak positif terhadap inflasi dan output.

\section{Kesimpulan}

Berdasarkan hasil analisis data dan pembahasan yang telah dikemukakan pada bab 4 dengan menggunakan metode Vector Error Correction Model (VECM) dapat disimpulkan dalam poin- poin berikut:

1. Berdasarkan hasil estimasi VECM , variabel SBI,SBIS,PUAB dan PUAS dalam jangka panjang berpengaruh secara signifkan terhadap tingkat inflasi di Indonesia, tetapi variabel LDR dan FDR 
Wicaksana, et al/Jurnal Ekonomi Syariah Teori dan Terapan Vol. 5 No. 12 Desember 2018: 10631078; INFLASI DI INDONESIA PADA PERIODE 2011-2015: ANALISIS SERTIFIKAT BANK INDONESIA, SERTIFIKAT BANK INDONESIA SYARIAH, PASAR UANG ANTAR BANK, PASAR UANG ANTAR BANK SYARIAH, FINANCE TO DEPOSIT RATIO DAN LOAN TO DEPOSIT RATIO

tidak berpengaruh pada jangka panjang.

2. Tidak terdapatnya pengaruh secara signifikan pada seluruh Variabel SBI,SBIS,PUAB,PUAS, LDR, dan FDR pada jangka pendek

3. Hasil Impulse response menunjukkan bahwa perubahan terhadap SBI direspon secara fluktuatif, namun cenderung positif terhadap IHK. Kemudian perubahan PUAB direspon juga secara fluktuatif, namun cenderung negatif terhadap IHK. Perubahan terhadap LDR direspon secara fluktuatif, namun cenderung negatif terhadap IHK. Perubahan terhadap SBIS direspon secara meningkat positi terhadap IHK, lalu perubahan pada PUAS direspon secara negatif terhadap IHK. Perubahan pada FDR cenderung meningkat positif terhadap IHK.

4. Hasil dari Variance decomposition dari $S B I, S B I S, P \cup A B, P \cup A S, L D R$, dan Finance to deposit ratio menunjukkan bawa variabel yang memiliki kontribusi terbesar dalam mempengaruhi perubaan variasi pada variabel IHK adalah Loan to Deposit Ratio, kemudian PUAB, diikuti
FDR, SBIS, PUAS, dan yang terkecil ialah SBI.

\section{DAFTAR PUSTAKA}

Ajija, S. R. 2011. Cara Cerdas Menguasai EViews.Salemba Empat. Jakarta

Anshori, M. dan Iswati, S. 2009. Buku Ajar Metodologi Penelitian Kuatitatif. Surabaya: Airlangga University Press.

Capra. 2000. Sistem Moneter Islam, Terjemahan oleh Ikhwan Abidin Basri.

Cahyono, Ari. 2009. Pengaruh Indikator

Makroekonomi Terhadap Dana Pihak

Ketiga Dan Pembiayaan Bank SyariahMandiri. Tesis. Universitas Indonesia

Karim, Adiwarman A. 2001. Ekonomi Islam: Suatu Kajian Kontemporer. Jakarta: Gema Insani Press

Mustafa, Edwin .2007. Pengenalan Eksklusif Ekonomi Islam Jakarta: Kencana Prenada Media Group

Rahardjo, Prathama dan Manurung, Mandala. 2001. Teori Ekonomi Makro, Penerbit Fakultas Ekonomi Universitas Indonesiaa

Rusydiana, Aam S, 2009 Mekanisme Transmisi Syariah Pada Moneter Ganda di Indonesia

Sugiyono. 2012. Metode Penelitian Kuantitatif Kualitatif dan R\&B. Bandung: Alfabeta.

Warjiyo, P dan J. Agung. 2002. Transmission Mechanism of Monetary Policy in Indonesia. Directorate of Economic Research and Monetary Policy. Bank Indonesia, Jakarta.

Triono, Dwi Condro. 2003. Pertumbuhan Ekonomi Versus Pemerataan Ekonomi. Irtikaz. Yogyakarta. 